\title{
Saccharification and Fermentation of Cellulolytic Agricultural Biomass to Bioethanol using Locally Isolated Aspergillus niger S48 and Kluyveromyces sp. Y2, respectively
}

\author{
Olumuyiwa Adeyemo ${ }^{*}$, Mohammed Ja'afaru², Sani Abudulkadir², Aishatu Salihu² \\ 1 Department of Biotechnology, School of Life Sciences, Modibbo Adama University of Technology, 64001 Yola, P.O.B. 2076, Nigeria \\ 2 Department of Microbiology, Modibbo Adama University of Technology, 64001 Yola, P.O.B. 2076, Nigeria \\ * Corresponding author, e-mail: omadeyemo@mautech.edu.ng
}

Received: 21 January 2021, Accepted: 23 May 2021, Published online: 16 August 2021

\begin{abstract}
Due to increase in demand for energy as a result of human population explosion, industrialization and environmental hazards posed by fossil fuels, there is a need to source for alternative energy sources that are cheaper and environmental friendly. Three different lignocellulosic biomasses were studied for their suitability for bioethanol production. Fungi and yeasts were isolated using serial dilution and spread plate methods. Identification of both fungi and yeasts was done using their cultural and microscopy characteristics. Saccharification of the pre-treated biomass was done with both crude cellulase and mycelia inoculant. Bioethanol was produced using batch culture fermentation. Ethanol produced was detected using spectrometric method and quantified using High Performance Liquid Chromatography (HPLC). The effects of substrate concentration, $\mathrm{pH}$ and temperature on ethanol yield were optimized. Fifty fungal isolates were obtained from soil collected. Six yeasts, all Kluyveromyces species fermented three sugars to ethanol with isolate Kluyveromyces sp.Y2 having the shortest time. It was selected for fermentation. Aspergillus niger S48 had highest cellulase activity measured in a zone of hydrolysis of $26.0 \mathrm{~mm}$. It had the highest glucanase activity, endoglucanase $(0.462 \mathrm{U} / \mathrm{mL})$ and exoglucanase $(0.431 \mathrm{U} / \mathrm{mL})$. The outcome of this study indicated that crude cellulase produced by Aspergillus niger S48 hydrolyzed the pre-treated rice chaff with $1.07 \mathrm{mg} / \mathrm{mL}$ of fermentable sugars higher than $0.87 \mathrm{mg} / \mathrm{mL}$ when the mycelia of the fungus was inoculated to pretreated rice chaff for hydrolysis. Ethanol was optimally produced at $12 \%$ substrate concentration using rice chaff, at a temperature of $35^{\circ} \mathrm{C}$ and $\mathrm{pH}$ 5.0.
\end{abstract}

Keywords

lignocellulolytic biomass, bioethanol, environmental friendly, alternative energy sources, endoglucanase, exoglucanase

\section{Introduction}

The fast rise of industrialization as well as population explosion demands that alternative sources of energy should be explored. Production of bioethanol using plant biomass or plant residues has been a viable option for this alternative [1]. Availability of energy is essential to the development of third world countries. There has been acute shortage of energy supply in these countries including Nigeria. However, with the abundance of plant biomass that if properly utilized can be used to produce bioethanol as an alternative renewable energy source in place of dwindling fossil fuel [2].

Biomass encompasses a wide range of materials from animals, plants and microorganisms. However, plant biomass has been of great interest due to their availability and their cheapness. They have low digestibility which makes them not competitive with other plant biomasses that are starchy and sugary in nature [3]. The use of starchy and sugary agricultural substrates has been substantially employed for bioethanol production, competing with human and animal foods and feeds. Therefore, there is a need to search for other suitable substrates that can be used for bioethanol production without affecting the human food supply [1]. This is one of the reasons why the attention of researchers shifted to lignocellulosic plant biomass for bioethanol production. Biomass occurs in nature with complex structures that are renewable [2].

Developing countries in sub-Saharan Africa are endowed with arable land for agriculture contributing heavily to the economy as well as plant residues. These countries have unquantifiable plant biomass that can be 
converted to bioethanol [4]. The addition of lignocellulosic renewable biomass will generate fuel, chemicals, energy in addition to reduction of green-house gases. This will also diversify job creation through biorefinery activities, with the use of abundant renewable biomass materials [5]. Bioethanol production from plant biomass has been of interest worldwide due to its usefulness without causing harm to the environment unlike fossil fuels that have been implicated in environmental pollution including global warming. The dependence of humanity on fossil fuels will be reduced significantly if attention could be given to the production of bioethanol [6].

The production of bioethanol from lignocellulosic materials involves three steps. First is the pre-treatment of the material to decrease the particle size and increase the contact surface area of the plant biomass with enzyme during saccharification [7, 8]. Lignoellulosic plant biomass consists of cellulose, hemicellulose and lignin. Pretreatment is usually done to remove lignin or reduce its concentration. This will enhance the hydrolysis of cellulose and hemicellulose either by chemical or enzymes to yield fermentable sugars that are converted to bioethanol during fermentation $[9,10]$. The fermentation of the sugars obtained from the hydrolysis to ethanol is the final step of the process $[7,8]$

For efficient bioethanol production using lignocellulosic plant biomass, the enzymes engaged for hydrolysis must adsorb to the biomass surface before the breaking down of the biomass will take place [8]. According to Vasić et al. [11], the breaking down of the pre-treated biomass using enzymes in the production of bioethanol is an essential step that will give rise to fermentable sugars. There has been non-stop search into finding more effective enzymes that will guarantee a cheaper production cost [11].

In Nigeria, agriculture is the major contributor of lignocellulosic plant biomass. This agricultural biomass is produced in large quantities and allowed to rotten on the field or burnt leading to environmental pollution [12]. Jekayinfa et al. [2] reported that in 2017 Nigeria produced 16.83 tonne/hectare of sugar cane biomass followed by 8.76 tonne/hectare of cassava. The least plant residue reported was 0.28 tonne/hectare of cocoa, though Nigeria is the fourth largest producer of cocoa in the world after Ivory Coast, Ghana and Indonesia [2].

Therefore, this study was carried out to evaluate three different lignocellulosic plant biomass which could be used for bioethanol production, to compare the effectiveness of either crude enzyme or direct fungi mycelial inoculation in hydrolysis of lignocellulosic plant biomass to fermentable sugars, to produce and optimize production parameters as well as to quantify the bioethanol produced.

\section{Materials and methods}

\subsection{Isolation of cellulolytic fungi and yeasts}

\subsubsection{Soil samples collection for fungi isolation}

The collection of soil samples was done at an agricultural waste dumping site at Hayin Gada and wood processing area, by-pass in Jimeta, Adamawa State, Nigeria. Soil samples were transported to the laboratory in Microbiology Department, Modibbo Adama University of Technology, Yola.

\subsubsection{Fungi and yeast isolation}

Isolation of fungi was performed after serial dilution using spread plate method. $1.0 \mathrm{~g}$ of each soil was serially diluted in $9.0 \mathrm{~mL}$ sterile distilled water in test tube to get $10^{-1}$ dilution. An aliquot, $0.1 \mathrm{~mL}$, from the $10^{-5}$ and $10^{-6}$ dilutions was spread onto Potato Dextrose Agar (PDA) plates that had chloramphenicol in it. Incubation of the plates was done at $28 \pm 2{ }^{\circ} \mathrm{C}$ for five days. Then, individual colony produced was sub-cultured to obtain pure cultures on PDA plates. Stock cultures were prepared by transferring pure cultures of the fungi to PDA agar slants in McCartney bottles. The inoculated slants were incubated at $28 \pm 2{ }^{\circ} \mathrm{C}$ until visible growth was observed. The stock cultures were preserved by storing in a refrigerator until further needed [13].

For yeast isolation, rotten orange and banana were collected from dumping sites within Bye Pass market, Jimeta/Yola, Adamawa State, Nigeria. The rotten orange and banana samples were cleaned by removing debris, stones and then washed in sterile distilled water. Each was sun-dried and homogenized using a mortar and pestle and then used for serial dilution. $0.1 \mathrm{~mL}$ of dilutions $10^{-4}$ and $10^{-5}$ was introduced to plates containing yeast extract peptone dextrose agar (YEPD agar) and spread uniformly. The plates were incubated for $24-48$ hours at $30{ }^{\circ} \mathrm{C}$ [14]. The plates were observed for growth of yeasts and individual colony was sub-cultured on YEPD agar to obtain pure cultures. The morphological characteristics of the isolates were observed and recorded. Stock cultures were prepared by transferring pure cultures of the yeast to YEPD agar slants in McCartney bottles. The inoculated slants were incubated at $28 \pm 2{ }^{\circ} \mathrm{C}$ until visible growth was observed. The stock culture was preserved by storing at $10 \pm 2{ }^{\circ} \mathrm{C}$ in a refrigerator until needed for further work. 


\subsection{Cultural characteristics of isolated fungi}

The following characteristics were examined: shape, color and color changes of colony and the reverse color of plates as well as texture of the surface of the colony as described by Saliu [15].

\subsubsection{Microscopy study of isolated fungi and yeast}

Briefly, a drop of mounting fluid of lactophenol-cotton blue solution was placed on a clean glass slide. Isolated pure yeast culture of 48 hours was transferred on to the fluid to make a smear with the stain. Clean cover slip with the help of forceps was placed on the smear. The excess stain was wiped with a blotting paper. The slides were observed under low to high power objectives microscope to study the shape of the cell and to know if buds were present or not. Furthermore, the mycelium of pure fungal culture of 5-7 days old was placed on a drop of lactophenol-cotton blue on a slide. The mycelium was teased with needle so as to separate the hyphae. The slide was with cover slip and viewed under compound microscope with objective lenses X10 and X40 [16].

\subsubsection{Identification of fungal and yeast isolates}

Selected fungi were identified using their colonial and cellular characteristics as compiled and referenced by Navi et al. [17], Unachukwu and Nwakanma [18] and Ravimannan et al. [19] for identification. Yeast were identified using the morphological and microscopy characteristics as documented by Ebabhi et al. [20]

\subsubsection{Screening of fungal isolates for cellulolytic activity} The method used to screen for cellulolytic activity in the isolated fungi was previously described by Mandels and Weber [21]. One percent (1 \% w/v) carboxyl methyl cellulose (CMC) was added to PDA and sterilized at $121{ }^{\circ} \mathrm{C}$ for $15 \mathrm{~min}$. The sterilized medium was cooled to room temperature and then dispensed into petri dishes aseptically. Each plate was inoculated with fungal isolate of 72 hours old culture with a straight line once across the plates. Incubation was done at $28 \pm 2{ }^{\circ} \mathrm{C}$ until visible growth was observed. Fungal isolates that were able to hydrolyze cellulose were observed after growth when the plates were flooded with $1 \%$ Congo red solution and allowed to stay for $15 \mathrm{~min}$. The Congo red dye was removed and $1 \mathrm{~N}$ sodium chloride solution was added to the growth on the plates which lasted for $15 \mathrm{~min}$. Zone of hydrolysis around the fungal growth was measured with ruler and recorded in millimeter. This measurement indicates fungal cellulase activity.

\subsection{Production and partial purification of cellulase}

One hundred milliliter of Mineral Salt medium was used to grow the inoculum [22]. The medium consists $3.0 \mathrm{~g}$ Urea,

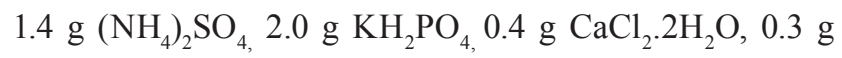
$\mathrm{MgSO}_{4} .7 \mathrm{H}_{2} \mathrm{O}, 0.75 \mathrm{~g}$ Peptone, $0.25 \mathrm{~g}$ Yeast extract, $0.005 \mathrm{~g}$ $\mathrm{FeSO}_{4} .7 \mathrm{H}_{2} \mathrm{O}, 0.0016 \mathrm{~g} \mathrm{MnSO}_{4} .7 \mathrm{H}_{2} \mathrm{O}, 0.0014 \mathrm{~g} \mathrm{ZnSO}_{4} .7 \mathrm{H}_{2} \mathrm{O}$, $0.002 \mathrm{~g} \mathrm{CoCl}_{2} 6 \mathrm{H}_{2} \mathrm{O}, 1000 \mathrm{~mL}$ distilled water, at $\mathrm{pH}$ of 4.8 and $2 \%(\mathrm{w} / \mathrm{v})$ carboxyl methyl cellulose (CMC). $5.0 \mathrm{~mL}$ sterile distilled water was used to wash off the fungal mycelia into a sterile conical flask. The mycelial suspension was used to inoculate the PDA slant. The spores obtained from the PDA slant were used to inoculate the sterile mineral salt medium. Incubation of the inoculated medium was done at $28 \pm 2{ }^{\circ} \mathrm{C}$ for 48 hours. After incubation, the spores were counted with the aid of a haemocytometer. The culture was standardized to approximately $4.2 \times 10^{5}$ spores per milliliter by diluting with Mandel's medium and used as inoculum for enzyme production [23].

Cellulase was produced using the medium Mandels Mineral Salt [23]. The medium contains $3.0 \mathrm{~g}$ Urea, $1.4 \mathrm{~g}\left(\mathrm{NH}_{4}\right)_{2} \mathrm{SO}_{4}, 2.0 \mathrm{~g} \mathrm{KH}_{2} \mathrm{PO}_{4}, 0.4 \mathrm{~g} \mathrm{CaCl}_{2} .2 \mathrm{H}_{2} \mathrm{O}, 0.3 \mathrm{~g}$ $\mathrm{MgSO}_{4} .7 \mathrm{H}_{2} \mathrm{O}, 0.75 \mathrm{~g}$ Peptone, $0.25 \mathrm{~g}$ yeast extract, $0.005 \mathrm{~g} \mathrm{FeSO}_{4} .7 \mathrm{H}_{2} \mathrm{O}, 0.0016 \mathrm{~g} \mathrm{MnSO}_{4} .7 \mathrm{H}_{2} \mathrm{O}, 0.0014 \mathrm{~g}$ $\mathrm{ZnSO}_{4} .7 \mathrm{H}_{2} \mathrm{O}, 0.002 \mathrm{~g} \mathrm{CoCl} \cdot 6 \mathrm{H}_{2} \mathrm{O}, 1000 \mathrm{~mL}$ distilled water, at $\mathrm{pH}$ of 4.8 and $2 \%(\mathrm{w} / \mathrm{v})$ carboxyl methyl cellulose (CMC). A hundred milliliter of the medium was inoculated with five milliliter of the inoculum culture and incubated at $28 \pm 2{ }^{\circ} \mathrm{C}$ for 10 days [23]. After incubation culture suspension was filtered using Whatman No.1 filter paper and then centrifuged at 10,000 rpm for $15 \mathrm{~min}$. The supernatant contained the crude enzyme and it was stored in sterile bottles in a refrigerator for further analysis.

\subsubsection{Partial purification of cellulase}

The filtrate obtained from the fermented broth was treated by the addition of ammonium sulphate (NH4) ${ }_{2} \mathrm{SO}_{4}$ to $500 \mathrm{~mL}$ of the filtered broth till saturation was obtained. The addition was gently carried out with continuous stirring. The suspension was centrifuged at 10,000 rpm for $10 \mathrm{~min}$ in a cold centrifuge at $4{ }^{\circ} \mathrm{C}$. The sediment was discarded while the precipitate was suspended in $0.05 \mathrm{M}$ phosphate buffer at $\mathrm{pH} 7.0$ was used to dissolve the precipitate [24]. The crude enzyme obtained was used for the hydrolysis of the pre-treated cellulolytic biomass. 


\subsection{Assay for cellulase activity}

\subsubsection{Determination of endoglucanase activity- carboxyl methyl cellulase (CMCase)}

Endoglucanase activity of the partially purified enzyme was done using the technique explained by Ghose [25] in International Union of Pure and Applied Chemistry. A mixture of crude enzyme of $0.5 \mathrm{~mL}$ and $0.5 \mathrm{~mL}$ of carboxyl methyl cellulose $(0.2 \% \mathrm{w} / \mathrm{v})$ was made in sterile test tubes containing $0.05 \mathrm{M}$ citrate buffer at $\mathrm{pH}$ 4.8. The blank was made up of $0.5 \mathrm{~mL}$ carboxyl methyl cellulose $(0.2 \% \mathrm{w} / \mathrm{v})$ in $0.05 \mathrm{M}$ citrate buffer at $\mathrm{pH}$ 4.8. Enzyme was not added. The test tube containing the mixture was then incubated at $50{ }^{\circ} \mathrm{C}$ for 1 hour. Furthermore, after incubation, three milliliter of dinitro-salicylic acid (DNSA) was introduced into the test tube to stop the enzyme activity. The test tube containing the mixture was placed in boiling water for $5 \mathrm{~min}$ and it was cooled down under a running tap water. After cooling, ten milliliter of sterile distilled water was added to the mixture in the test tube. The absorbance was taken at $540 \mathrm{~nm}$ using Thermo Scientific Spectrophotometer. A glucose standard was made by varying the concentration of glucose from 0.1 to $2.0 \mathrm{mg} / \mathrm{mL}$. The blank was treated the same way. The absorbance readings were plotted against concentrations of glucose from which a calibration curve was obtained. The quantity of reducing sugars released was determined using the calibrated curve. One unit of enzyme activity was taken to be the measure of the enzyme that released $1 \mu \mathrm{M}$ of reducing sugar per milliliter of substrate per minute.

\subsubsection{Determination of exo-glucanase activity- Filter Paper assay (FPase)}

The method described by Mandels et al. [23] was used to assess the exoglucanase activity of the crude enzyme. $1.0 \mathrm{~mL}$ of the enzyme and $1.0 \mathrm{~mL}$ of citrate buffer of $\mathrm{pH}$ 4.8 were mixed in a test tube. Filter paper strip was dipped into the test tube containing the mixture. The filter paper strip was used as the substrate. The test tube content was incubated at $50{ }^{\circ} \mathrm{C}$ for 1 hour. After the incubation period, three milliliter of DNSA was then added to the mixture in the test tube to end the assay. The content in the test tube was boiled in a water bath for $15 \mathrm{~min}$ and it was cooled under a tap running water. Distilled water of $10 \mathrm{~mL}$ was introduced into the test tube and mixed thoroughly. Absorbance was read off at $540 \mathrm{~nm}$ and concentration of sugar interpreted from glucose calibration curve. The activity of the enzyme of one unit was said to be amount that was able to yield $1.0 \mu \mathrm{M}$ of reducing sugar per milligram of substrate per minute [23].

\subsection{Sugar fermentation test}

The ability of isolated yeasts to ferment different sugars to alcohol was carried out. The sugars used were glucose, lactose and sucrose. The fermentation media comprises of $10.0 \mathrm{~g}$ peptone, $5.0 \mathrm{~g}$ sodium chloride, $10.0 \mathrm{~g}$ each of glucose, lactose, sucrose, and $0.25 \%$ phenol red and $1000 \mathrm{~mL}$ distilled water. The medium in a test tube with Durham's tube was warmed for few minutes in a water bath. The medium inoculated with pure yeast culture and incubation took place at $28 \pm 2{ }^{\circ} \mathrm{C}$ for two days. [26].

\subsection{Production of bioethanol from plant wastes}

\subsubsection{Collection and pre-treatment of plant wastes}

Three different plant materials such as peels obtained from yam, the shells of groundnut and rice chaff used in this work were obtained from the Jimeta market. All the plant materials were cleaned to remove dirt. They were sun dried for 48 hours. The dried plant biomasses were grinded with the aid of mortar and pestle and it was powdered and sieved through $100 \mu \mathrm{m}$ pore size.

\subsubsection{Pre-treatment of plant biomass with alkali}

The sieved powdered plant materials were pre-treated individually using alkali according to the method of Vyas et al. [27]. This opened up the hydrolyzates for enzymatic actions. Powdered plant biomass $(50 \mathrm{~g})$ was weighed into a $500 \mathrm{~mL}$ Erlenmeyer flask containing $250 \mathrm{~mL}$ of $0.25 \mathrm{M}$ sodium hydroxide solution and autoclaved at $121^{\circ} \mathrm{C}$ for 1 hour. The samples were kept in suspension for 24 hours after which they were washed several times with distilled water. The $\mathrm{pH}$ of the water was adjusted to $\mathrm{pH} 7.0$ with $\mathrm{HCl}$ or $\mathrm{NaOH}$ depending on the initial $\mathrm{pH}$ value. The residue was drained using muslin cloth and then dried in electric oven at $65{ }^{\circ} \mathrm{C}$ until it can be powdered. The dried powder was then stored in a sealed polythene bags at room temperature.

\subsubsection{Saccharification of plant wastes using fungal isolate}

The inoculum for the hydrolysis of biomass was developed by inoculating five day old culture of the fungi in to a sterile mineral salt medium composed of $3.0 \mathrm{~g}$ Urea, $1.4 \mathrm{~g}\left(\mathrm{NH}_{4}\right)_{2} \mathrm{SO}_{4}, 2.0 \mathrm{~g} \mathrm{KH}_{2} \mathrm{PO}_{4}, 0.4 \mathrm{~g} \mathrm{CaCl}_{2} .2 \mathrm{H}_{2} \mathrm{O}$, $0.3 \mathrm{~g} \mathrm{MgSO}_{4} .7 \mathrm{H}_{2} \mathrm{O}, 0.75 \mathrm{~g}$ Peptone, $0.25 \mathrm{~g}$ yeast extract, $0.005 \mathrm{~g} \mathrm{FeSO}_{4} .7 \mathrm{H}_{2} \mathrm{O}, 0.0016 \mathrm{~g} \mathrm{MnSO}_{4} .7 \mathrm{H}_{2} \mathrm{O}, 0.0014 \mathrm{~g}$ $\mathrm{ZnSO}_{4} \cdot 7 \mathrm{H}_{2} \mathrm{O}, 0.002 \mathrm{~g} \mathrm{CoCl}_{2} .6 \mathrm{H}_{2} \mathrm{O}, 1000 \mathrm{~mL}$ distilled water, at $\mathrm{pH}$ of 4.8 and $1 \%(\mathrm{w} / \mathrm{v})$ carboxyl methyl cellulose (CMC) [23]. After 48 hours of incubation at $30{ }^{\circ} \mathrm{C}$, the inoculum was calibrated using haemocytometer to 
approximately $4.2 \times 10^{5}$ spores per milliliter by diluting with sterile distilled water. $100 \mathrm{~mL}$ of Mandels' medium was adjusted to $\mathrm{pH} 4.8$, mixed with $10 \%$ (w/v) alkaline treated cellulosic waste materials (i.e. rice chaff, groundnut shell and yam peel) and it was autoclaved at $121{ }^{\circ} \mathrm{C}$ for $15 \mathrm{~min}$. The autoclaved mixture was allowed to cool to room temperature and it was inoculated with $5.0 \mathrm{~mL}$ of the fungal inoculum. Incubation took place at $30{ }^{\circ} \mathrm{C}$ for six days and the reaction was observed every 24 hours for sugar yield [23]. For each day, $1.0 \mathrm{~mL}$ of centrifuged supernatant was removed and mixed with $3.0 \mathrm{~mL}$ of DNSA in a test tube. The mixture was boiled for five minutes in a water bath and then placed under a flowing tap water to cool it. The spectrophotometer was set at $540 \mathrm{~nm}$ wavelength and the absorbance was taken. However, the calibration curve was plotted using glucose as the standard.

\subsubsection{Enzymatic hydrolysis of pre-treated substrate into fermentable sugars}

Saccharification of the pre-treated biomass was carried out using the illustration of [28]. Ten gram of biomass each (rice chaff, groundnut shell and yam peel) was added into conical flasks that contains $100 \mathrm{~mL}$ of citrate buffer at $\mathrm{pH} 4.8$ and sterilized in an autoclave at $121{ }^{\circ} \mathrm{C}$ for $15 \mathrm{~min}$. The sterilized pre-treated biomass was treated with ten milliliter of the crude cellulase. The flask with its content was incubated for 7 hours at $50{ }^{\circ} \mathrm{C}$ during which a milliliter of the enzyme treated biomass was taken per hour to determine the sugar yield. The sugar analysis was done using the method described by Mandels et al. [23]. The absorbance was read at $540 \mathrm{~nm}$ wavelength in a spectrophotometer. The amount of sugars released was obtained from calibration curve obtained by using glucose as the standard and expressed as $\mathrm{mg} / \mathrm{mL}$.

\subsubsection{Inoculum for the fermentation of hydrolyzed biomass}

A 48 hour culture of the selected yeast was introduced into a conical flask that contains 100 milliliter of yeast extract peptone medium incorporated with hydrolyzed biomass and incubated for 48 hours. After which, the inoculum size of $4.2 \times 10^{5}$ spores per milliliter was determined using a haemocytometer and it was used for inoculation.

\subsubsection{Fermentation of hydrolyzed biomass}

Fermentation medium consisted of enzyme, hydrolyzed biomass, yeast extract and peptone at $20 \mathrm{~g}$ each per 1.0 liter of distilled water, $\mathrm{pH}$ adjusted to 4.8 using dilute hydrochloric acid. The medium was sterilized in an autoclave at $121{ }^{\circ} \mathrm{C}$ for $15 \mathrm{~min}$. The medium was cooled to room temperature, and $10 \mathrm{~mL}$ of inoculum (yeast) was added. Incubation was done at $30{ }^{\circ} \mathrm{C}$ for 48 hours [15].

\subsubsection{Test for the presence of ethanol by potassium dichromate and sulphuric acid method}

The presence of ethanol was determined by spectrometric method and ethanol standard curve illustrated by Caputi [29]. $1.0 \mathrm{~mL}$ of the fermented hydrolyzate was added to $5.0 \mathrm{~mL}$ of distilled water, $1.0 \mathrm{~mL}$ of $\mathrm{K}_{2} \mathrm{Cr}_{2} \mathrm{O}_{7}$ and $4 \mathrm{~mL}$ of conc. $\mathrm{H}_{2} \mathrm{SO}_{4}$ were all added together in a test tube. The ethanol standard was prepared with concentration that ranged from $0.1 \mathrm{mg} / \mathrm{mL}$ to $1.0 \mathrm{mg} / \mathrm{mL}$. Ethanol blank also prepared by adding $1 \mathrm{~mL}$ of buffer, with $1 \mathrm{~mL}$ of $\mathrm{K}_{2} \mathrm{Cr}_{2} \mathrm{O}_{7}$ and $4 \mathrm{~mL}$ of conc. $\mathrm{H}_{2} \mathrm{SO}_{4}$ as the reaction mixture. The intensity of color was taken at $660 \mathrm{~nm}$ wavelength in a spectrophotometer. The absorbance was plotted against concentration of ethanol to obtain a calibration curve. Ethanol production was assayed by comparing with standard graph.

\subsection{Optimization of bioethanol production and determination of bioethanol yield using High Performance Liquid Chromatography (HPLC)}

\subsubsection{Optimization of bioethanol production}

The optimization of ethanol production was carried out using three parameters. These were substrate concentration, incubation temperature and $\mathrm{pH}$ of the medium

Different substrate concentrations of $8 \%, 10 \%$ and $12 \%$ were prepared by adding appropriate amount of enzyme hydrolyzed rice chaff to the production media. The $\mathrm{pH}$ of the mixture was adjusted to 5.0 using dilute hydrochloric acid. The mixture was sterilized at $121{ }^{\circ} \mathrm{C}$ for $15 \mathrm{~min}$ and allowed to cool room temperature. Conical flask containing the sterilized medium was inoculated with ten milliliter of the yeast inoculum. Incubation was carried out at $30{ }^{\circ} \mathrm{C}$ for 48 hours. The ethanol yield was determined by HPLC. Briefly, the fermented broth was filtered using Whatmann filter paper Nol. The ethanol concentration was determined using Agilent 1200 HPLC system with Hiplex $\mathrm{H}$ column coupled with refractive index detector. High purity water was used to clean the column at the rate of $0.2 \mathrm{~mL} / \mathrm{min}$ at a temperature of $60{ }^{\circ} \mathrm{C}$. This was done overnight. Further cleaning was done with $25 \mathrm{mM}$ sulphuric acid for some hours under the same condition, which was carried out after each batch of analysis. The conditions needed for the analysis (sample volume, 
flow rate, running time and temperature) were entered in to the computer system and allow the program to run automatically. The sample volume was $10.0 \mu \mathrm{L}$ which was automatically injected onto the column by itself, and carried at the rate of $0.4 \mathrm{~mL} / \mathrm{min}$ for 20 min with $14 \mathrm{mM}$ $\mathrm{H}_{2} \mathrm{SO}_{4}$ as the mobile phase and $40^{\circ} \mathrm{C}$ as the column temperature. The detection of the analytes was by refractive index signal. The signals were read from the detector to know the elution time of the targeted ethanol. The substrate concentration that produced the highest ethanol was kept constant for subsequent parameter optimization.

Three conical flasks containing sterile fermentation medium with $12 \%$ substrate concentration, was adjusted to $\mathrm{pH} 4.5,5.0$ and 5.5 with hydrochloric acid. Sterilization of the medium was done in an autoclave at $121{ }^{\circ} \mathrm{C}$ for $15 \mathrm{~min}$. It was then cooled to room temperature. Ten milliliter of the yeast inoculum was introduced into each conical flask. The flask was incubated at $30{ }^{\circ} \mathrm{C}$ for 48 hours. The ethanol produced was quantified with HPLC.

The already optimized parameters such as substrate concentration at $12 \%$ and $\mathrm{pH}$ at 5.0 remained constant while the optimizing temperature. Three different conical flasks with optimized conditions were autoclaved for 15 min at $121{ }^{\circ} \mathrm{C}$ and allowed to cool to room temperature, $10.0 \mathrm{~mL}$ of the yeast inoculum was added to each of the conical flask and incubation was done for 48 hours at varying temperature of $30^{\circ} \mathrm{C}, 35^{\circ} \mathrm{C}$ and $40^{\circ} \mathrm{C}$.

\section{Results and discussion}

Fossil fuel has been the major global source of energy for years. This includes crude oil, liquefied natural gases as well as coal. However, they are being depleted at a fast rate due to human activities and may be exhausted sooner than expected due to that fact that they are not renewable. Besides these, they generate a lot of concern due to their negative environmental impacts. Hence, a clean source of energy such as bioethanol will be a suitable replacement to fossil fuel.

\subsection{Cellulolytic fungi and yeasts from soil and rotten fruits}

Twenty fungi exhibited cellulase activity out of the fifty isolates obtained during isolation.

However, isolates S46, S47 and S48 showed promising cellulolytic activity. The highest zone of hydrolysis recorded in this work was $26.0 \mathrm{~mm}$ with Aspergillus niger S48 while the lowest was $24 \pm 0.6$ and $24 \pm 0.4 \mathrm{~mm}$ with both isolates Aspergillus niger S46 and Aspergillus niger S47, respectively (Fig. 1). These values recorded in this study were less than $54.33 \mathrm{~mm}$ that was reported by Abd Elrsoul and Bakhiet [30]. However, the zone of hydrolysis we reported were higher compared to $0.7 \pm 0.13 \mathrm{~cm}$ and $0.5 \pm 0.11 \mathrm{~cm}$ that were reported by Ordaz-Diaz et al. [31] for Aspergillus niger and Aspergillus fumigatus, respectively. The differences observed in the zone of hydrolysis could be attributed to the cellulase activity by the different strains of Aspergillus used in the study [32].

\subsection{Identification of fungal isolates}

In Table 1, the twenty fungal isolates that were positive for cellulase activity belong to five different species of Aspergillus. They were identified based on their morphological and microscopic characteristics. Aspergillus niger

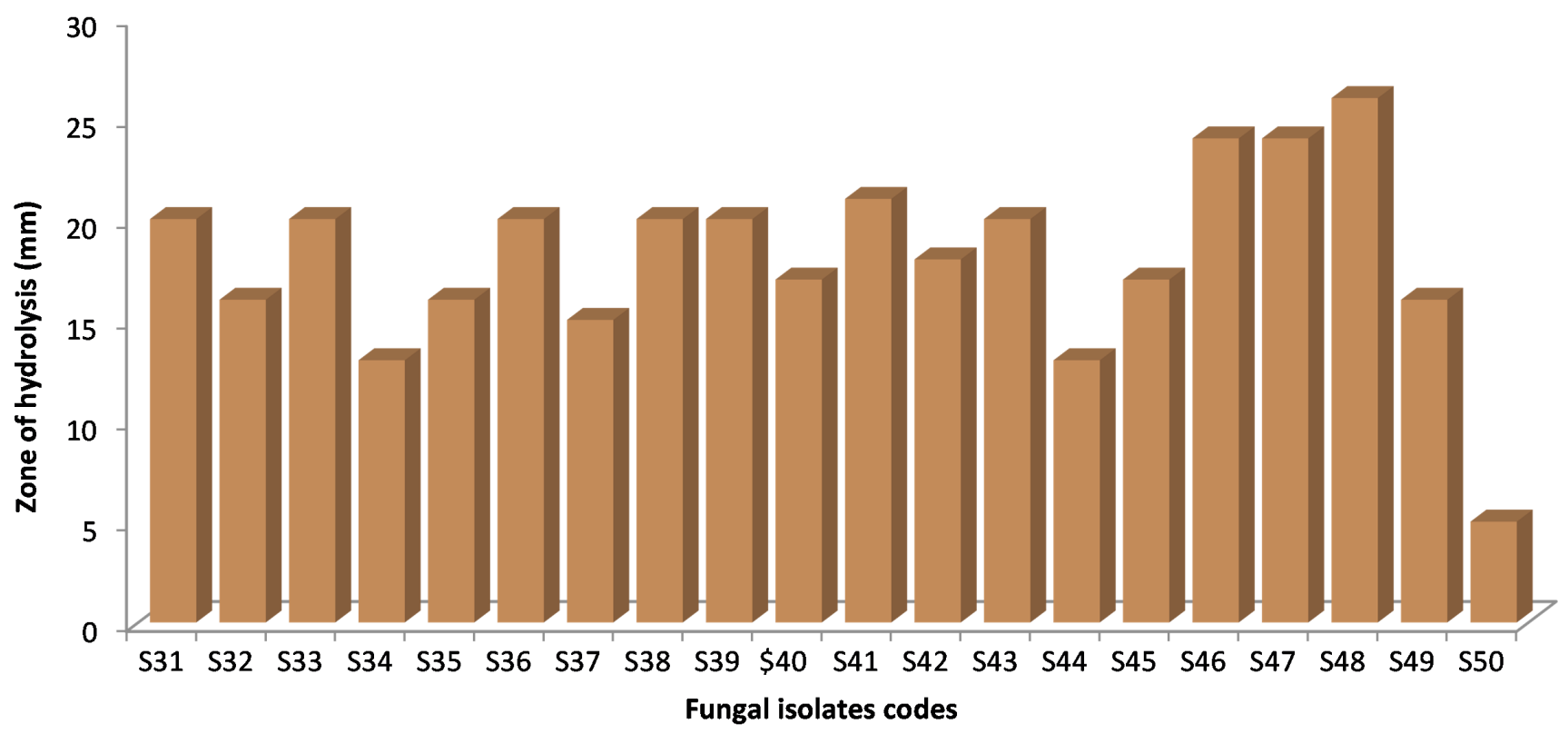

Fig. 1 Cellulase activity of isolated fungi in zone of hydrolysis measured in millimeter 
Table 1 Cultural and microscopic characteristics of cellulolytic fungal isolates

\begin{tabular}{|c|c|c|c|}
\hline Fungal isolates and codes & Cultural characteristics of the fungi & Microscopy characteristics & Probable identity of the fungi \\
\hline $\begin{array}{l}\text { S31, S32, S34, S36, S38, } \\
\text { S39, S40, S42, S43, S46, } \\
\text { S47 and S48 }\end{array}$ & $\begin{array}{l}\text { Fungal colonies were velvet, compact and with } \\
\text { round shape. It appeared whitish initially but } \\
\text { turned black after few days. It appeared creamy } \\
\text { on the reverse side of the plate }\end{array}$ & $\begin{array}{l}\text { Hyphae are septate with } \\
\text { globose and with rough } \\
\text { Conidiosphore }\end{array}$ & Aspergillus niger \\
\hline S37, S41, S45 and S49 & $\begin{array}{l}\text { Colonies of these isolates looked velvet with } \\
\text { round shape. It was initially yellow but changed } \\
\text { to green with time. The reverse side of the plate } \\
\text { was creamy in color }\end{array}$ & $\begin{array}{l}\text { Hyphae are septate, oval and } \\
\text { with smooth coniodiosphore }\end{array}$ & Aspergillus flavus \\
\hline S35 and S44 & $\begin{array}{c}\text { Colonies was velvet in appearance and round in } \\
\text { shape. It was initially white but turned black with } \\
\text { aging. The reverse side color of the colonies was } \\
\text { cream }\end{array}$ & $\begin{array}{l}\text { Hyphae are septate with } \\
\text { elliptical and rough } \\
\text { Conidiosphore }\end{array}$ & Aspergillus fumigatus \\
\hline S32 & $\begin{array}{l}\text { The colony of the isolate appeared velvet with } \\
\text { round shape. It was white initially but turned } \\
\text { green with time. The reverse side color in the } \\
\text { plate appeared creamy }\end{array}$ & $\begin{array}{l}\text { Hyphae are septate with } \\
\text { ellipsoid and smooth } \\
\text { Conidiosphore }\end{array}$ & Aspergillus clavatus \\
\hline $\mathrm{S} 50$ & $\begin{array}{l}\text { The colony appearance was velvet, compact and } \\
\text { round in shape. It was white initially but changed } \\
\text { to brown at maturity. The reverse side colored } \\
\text { observed on the plate was yellow }\end{array}$ & $\begin{array}{l}\text { Hyphae are septate with } \\
\text { globuse and smooth } \\
\text { conidiosphore }\end{array}$ & Aspergillus terreus \\
\hline
\end{tabular}

was highest with twelve isolates while both Aspergillus flavus and Aspergillus terreus had only one isolate. They all appeared velvet on plate with different colors at the early and later stages. Cultural characteristics such as the colors formed on the surface and the reverse side by the isolate as well as microscopy attributes when observed under microscope were used to identify the selected fungi to the genus level (Table 1). Cultural characteristics fungi had been identified to be valuable tool in the identification of fungi [33]. The result observed in this study was in agreement with the previous reports of Bakhiet and Al-Mokhtar [34] and Alsohaili and Bani-Hasan [35] that identified the fungi isolates they worked with using the morphological and microscopy characteristics.

\subsection{Endoglucanase and exoglucanase activity}

Endoglucanase activity in submerged fermentation by the selected fungi, Aspergillus niger S46, Aspergillus niger S47 and Aspergillus niger S48 shown in Fig. 2 indicated that highest endoglucanase activity was recorded in Aspergillus niger S48 $(0.460 \mathrm{U} / \mathrm{mL})$, followed by Aspergillus niger $\mathrm{S} 47(0.394 \mathrm{U} / \mathrm{mL})$ while the least was observed in Aspergillus niger S46 (0.328 U/mL). Both endoglucanase and exoglucanase are jointly responsible for the sugar yielded from the biomass. The results obtained in this study for both endoglucanase and exoglucanases were higher than values mentioned by Saliu and Sani [33] that reported $0.17 \mathrm{U} / \mathrm{mL}$ and $0.05 \mathrm{FPU} / \mathrm{mL}$ for both exoglucanase and endoglucanase activities but less than the values reported by Abd Elrsoul

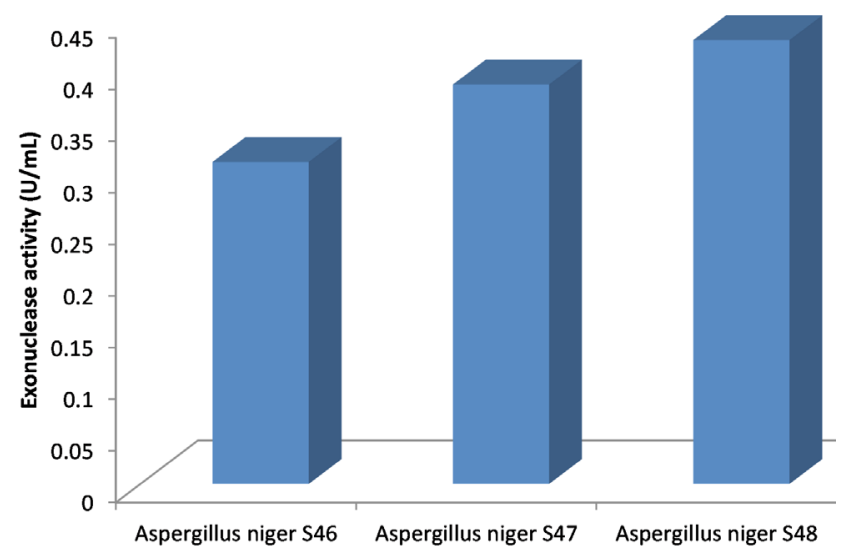

Fig. 2 Endonuclease activity of the selected fungi isolates

and Bakhiet [30] who reported $2.90 \mathrm{U} / \mathrm{mL}$. The value of endoglucanase activity being presented in this study for the three species of Aspergillus $(0.328 \mathrm{U} / \mathrm{mL}, 0.394 \mathrm{U} / \mathrm{mL}$ and $0.460 \mathrm{U} / \mathrm{mL}$ ) were higher than $0.300 \mathrm{U} / \mathrm{mL}$ reported by Sohail et al. [36] obtained from Aspergillus niger MS82. The differences observed could be attributed to inductions of these enzymes by the substrates [33] and production conditions [30]. Moreover, taking the readings of the enzyme activity at a fixed time instead of over a range or interval of time could have influenced the reading presented in our report.

Furthermore, Aspergillus niger S48 had the highest exoglucanase activity of $0.430 \mathrm{UmL}^{-1}$ while isolate Aspergillus niger S47 exhibited exoglucanase activity of $0.387 \mathrm{U} / \mathrm{mL}$ and the lowest exoglucanase activity of $0.312 \mathrm{U} / \mathrm{mL}$ was observed with Aspergillus niger S46 as 


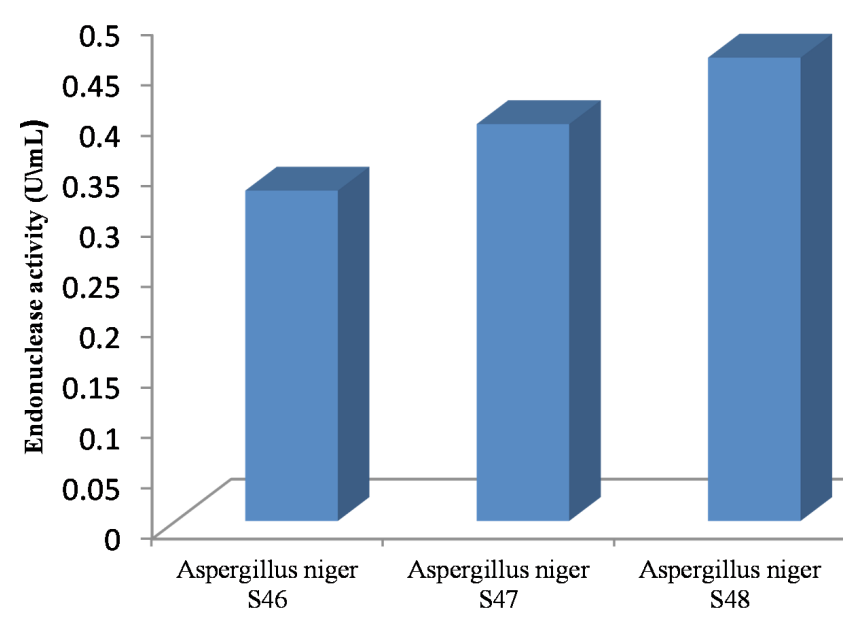

Fig. 3 Exonuclease activity of the selected fungi isolates

presented in Fig. 3. The exoglucanase activity obtained in this study with the three Aspergillus niger species worked with were less compared to what was published by Alawlaq and Alharbi [37] who reported 5.90 U/g. The difference could be attributed to different substrates, fermentation conditions and fungi used for the study [30].

\subsection{Isolation, characterization and identification of yeast}

Thirty yeasts were isolated from rotten orange and banana. This number was low compared to Rao et al. [38] who reported the isolation of 374 yeasts from rotten fruit and bark of trees. Sampling size could be responsible for the difference in the number of yeasts obtained. Twenty four of them were identified to be Saccharomyces species while six were Kluyveromyces species based on their colonial and microscopy characteristics (Table 2). Saccharomyces species were unable to ferment lactose while all the species of Kluyveromyces fermented all the three sugars to ethanol. However, Kluyveromyces sp. Y2 spent less time of 12 hours to ferment all the sugars to ethanol while the remaining five species of Kluyveromyces took between 16 and 17 hours to ferment the sugars to ethanol (Fig. 4). The fermentation of hydrolyzed cellulolytic biomass to ethanol was carried out with yeast. Different species of yeasts are known to ferment sugars to ethanol. The results obtained in this work was in tandem with earlier report of Rao et al. [38] who isolated yeasts that could be used for bioethanol production from rotten fruits and bark of a tree. Among the genera of yeasts reported by Rao et al. [38] was Kluyveromyces. The yeast isolate used in this study Kluyveromyces sp. Y2 was observed to ferment all the three sugars in shortest time (Fig. 4).

\subsection{Pre-treatment and saccharification of plant wastes to hydrolysable sugars}

The hydrolysis of pretreated agricultural waste using Aspergillus niger S48 as inoculant is as shown in Fig. 5. The highest concentration of sugars $(0.87 \mathrm{mg} / \mathrm{mL})$ was obtained from the rice chaff followed by yam peel which produced $0.70 \mathrm{mg} / \mathrm{mL}$ while groundnut shell produced lowest sugar release of $0.52 \mathrm{mg} / \mathrm{mL}$.

The hydrolysis of rice chaff, ground nut shell and yam peel using crude cellulase enzyme presented in Fig. 6 showed that highest concentration of sugars $(1.07 \mathrm{mg} /$ $\mathrm{mL}$ ) was produced from the rice chaff, followed by yam peel which produced $0.87 \mathrm{mg} / \mathrm{mL}$ while groundnut shell produced lowest sugar concentration of $0.75 \mathrm{mg} / \mathrm{mL}$. Kolajo [39] mentioned in her report that cellulase enzymes yielded more $(4.04 \mathrm{mg} / \mathrm{mL})$ fermentable sugars than dilute acid or alkali that produced $3.76 \mathrm{mg} / \mathrm{mL}$. This reaffirms the report being presented that crude cellulase produced by Aspergillus niger S48 hydrolyzed pre-treated lignocellulosic agricultural biomass to fermentable sugars. Similarly, the report of Manmai et al. [40] showed that chemical treatment of sunflower stalk yielded more sugars $5.8 \mathrm{mg} / \mathrm{mL}$ than when Trichoderma reesei was used for hydrolysis

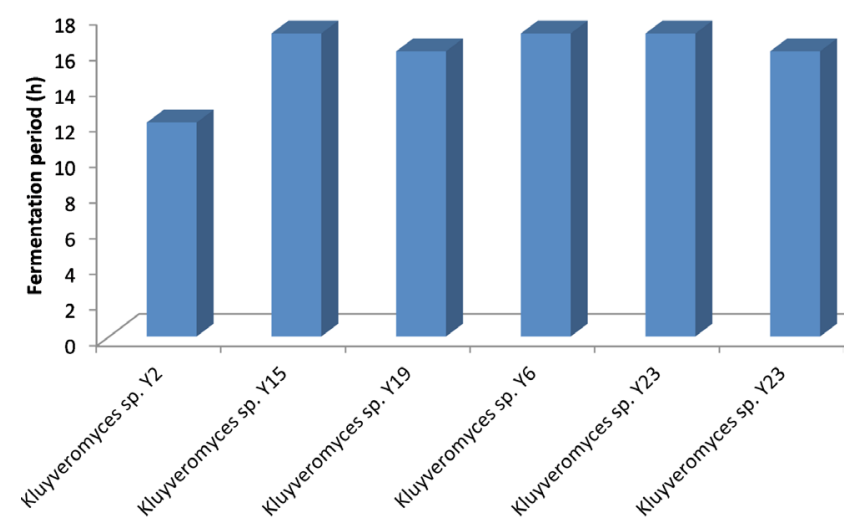

Fig. 4 Fermentation period of selected yeasts

Table 2 Cultural, microscopic characteristics and sugars fermentation potential of yeast isolates

\begin{tabular}{lccc}
\hline Number of isolates & Cultural characteristics & Microscopy characteristics & Sugars fermented \\
\hline 24 & $\begin{array}{c}\text { These isolates grow fast and } \\
\text { creamy-white in color }\end{array}$ & $\begin{array}{c}\text { Spherical in shape with } \\
\text { buds attached to the parent } \\
\text { colony }\end{array}$ & Glucose and sucrose \\
6 & $\begin{array}{c}\text { The colonies appeared creamy } \\
\text { in color }\end{array}$ & $\begin{array}{c}\text { Ring-like in shape without } \\
\text { shape with bud formation }\end{array}$ & $\begin{array}{c}\text { Glucose, sucrose and } \\
\text { lactose }\end{array}$ \\
\hline
\end{tabular}




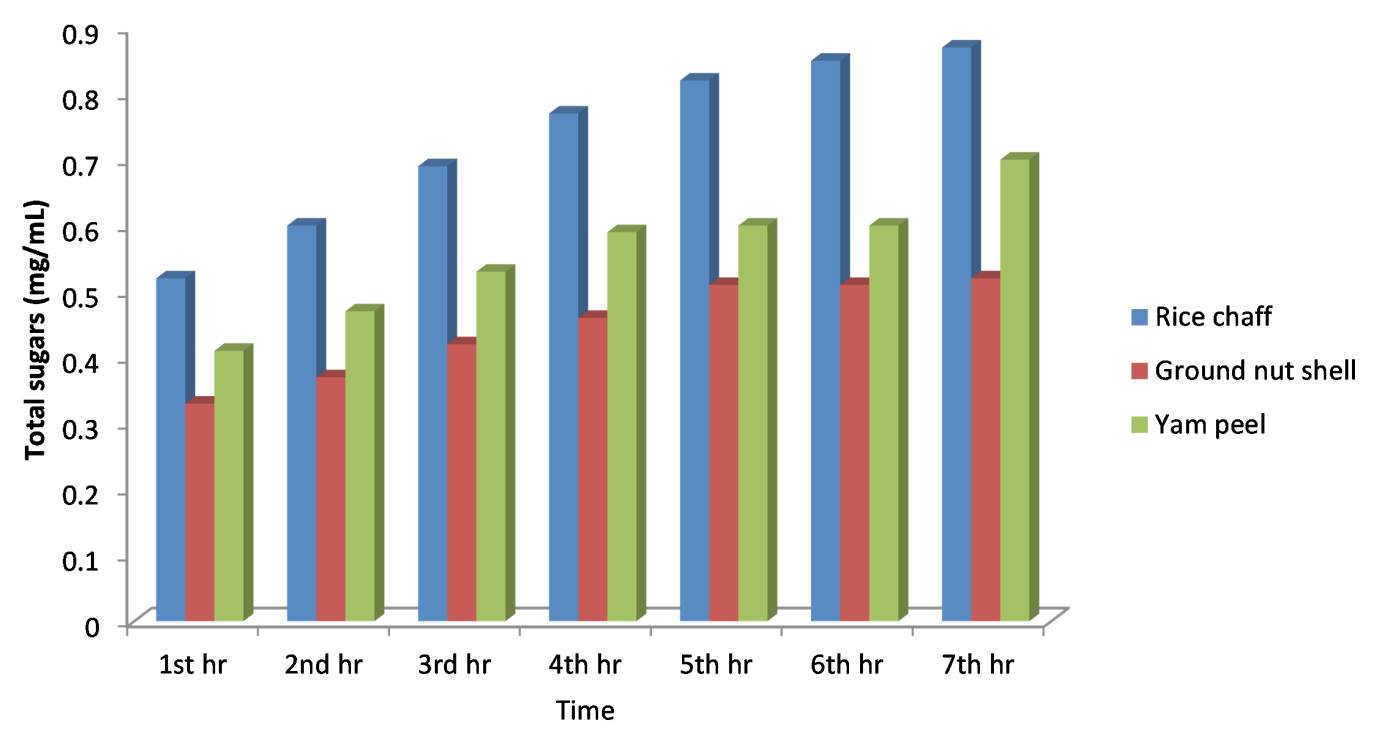

Fig. 5 Hydrolysis of Rice chaff, Ground nut shell and Yam peels by Aspergillus niger S48 as inoculant

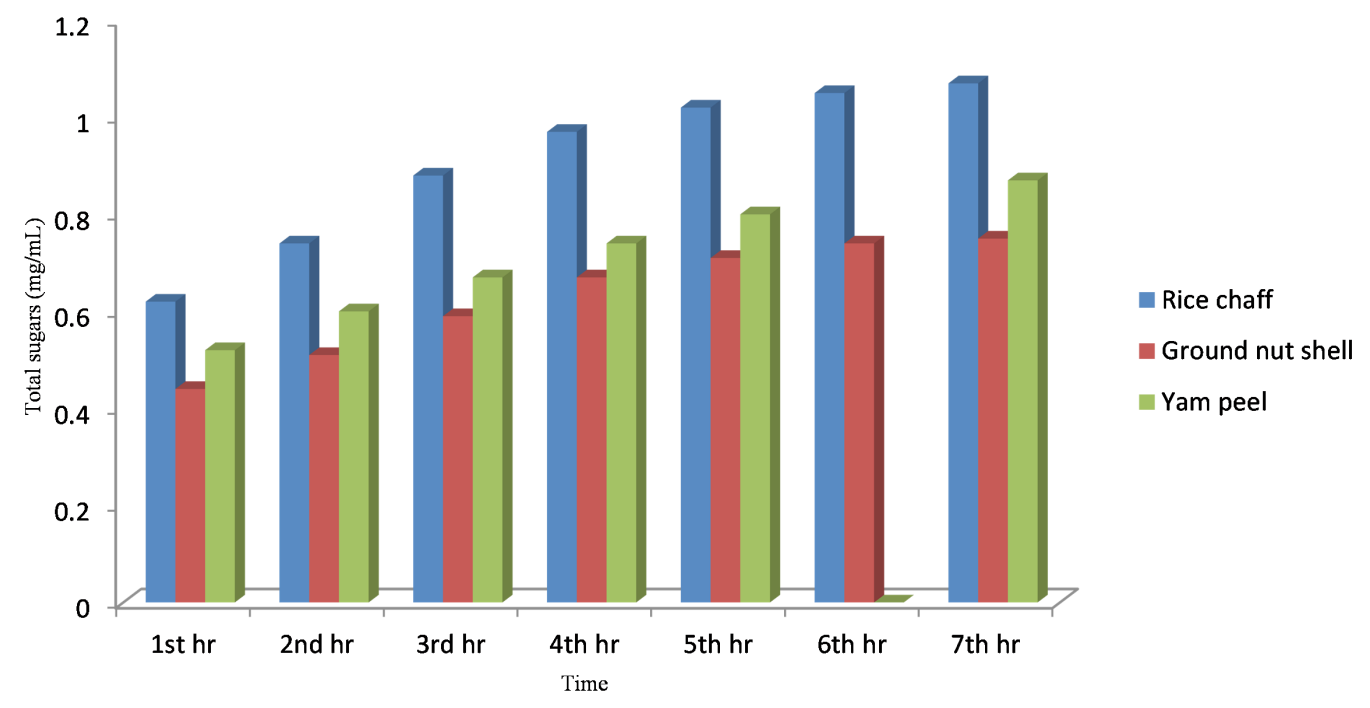

Fig. 6 Hydrolysis of Rice chaff, Ground nut shell and Yam peels using crude cellulase produced by Aspergillus niger S48

$3.9 \mathrm{mg} / \mathrm{mL}$. This implies that hydrolytic enzymes are produced by different fungal isolates. The values of yielded sugars obtained in this study were less compared to the report of Manmai et al. [40] though different plant biomass and hydrolytic enzyme-producing fungi were used in the studies. The differences observed in our results and the reports of these authors could be due to differences in chemical concentration used and the different enzyme activities. The fermentable sugar yields being reported in this study were less than earlier report of Ja'afaru and Fagade [41] who reported $5.55 \mathrm{mg} / \mathrm{mL}$ as well as Saliu and Sani [33] that mentioned a yield of $7.63 \mathrm{mg} / \mathrm{mL}$ from corn cob as substrate. Several factors such as temperature, moisture content, incubation period, carbon and nitrogen sources, $\mathrm{pH}$ as well as the species of microorganisms used for the hydrolysis of the lignocellulosic plant biomass have been mentioned to influence the outcome of biological treatment [32]. Beside these, cellulase activity has also been implicated as a factor that affects the hydrolysis of pre-treated lignocellulosic plant biomass [32].

Saccharification of cellulolytic biomass is one of the main steps in production of ethanol from green biomass. In this study an attempt was made to use the direct inoculation of Aspergillus niger S48 and also the crude cellulase synthesized by the fungus to hydrolyze the pre-treated biomass, this stage of the process involves conversion of complex cellulosic substrates to utilizable sugars. The report of Chand et al. [42] has previously stated that the recovery of utilizable sugars by yeast as well as cellulase production determine how much the process will cost 
and recovery of fermentable sugars after enzymatic saccharification are the important factors that affect the cost of the process. The direct use of crude enzyme yielded more fermentable sugars that was converted to ethanol by the yeast Kluvyveromyces sp. Y2 as it was observed in this study (Fig. 6). Narra et al. [43] reported the use of a thermo-tolerant species of Kluyveromyces to hydrolyze and to ferment sugars obtained from cellulosic biomass to bioethanol. The observation in this study was in consonance with the previous report of Hashem et al. [44] that mentioned a species of Kluyveromyces was used as the fermenting yeast in the production of ethanol. Other authors such as Saliu and Sani [33] and Abada et al. [45] employed Saccharomyces cerevisiae to carry out the fermentation of hydrolyzed cellulolytic biomass to ethanol.

\subsection{Fermentation and optimization conditions of hydrolyzed biomass to ethanol}

Fermentation conditions such as rice chaff concentrations of $8 \%, 10 \%, 12 \%$, temperature of $30{ }^{\circ} \mathrm{C}, 35^{\circ} \mathrm{C}$ and $40{ }^{\circ} \mathrm{C}$ as well as and $\mathrm{pH}$ values of 4.5, 5.0 and 5.5 were studied to optimize the ethanol production. The highest quantity of ethanol $0.424 \mathrm{mg} / \mathrm{mL}$ was produced at substrate concentration of $12 \%$, temperature of $35^{\circ} \mathrm{C}$ and $\mathrm{pH}$ of 5.0. The least quantity of $0.40 \mathrm{mg} / \mathrm{mL}$ was produced at a substrate concentration of concentration of $8 \%$, temperature of $30{ }^{\circ} \mathrm{C}$ and $\mathrm{pH}$ of 4.8 (Table 3). Temperature above $35^{\circ} \mathrm{C}$ for instance has been said to affect ethanol yield. A temperature of $35{ }^{\circ} \mathrm{C}$ and a $\mathrm{pH}$ between 5.0-5.2 are known to be ideal for optimized fermentation by yeasts which are comparable to the result obtained in this study [43]. Reports of Ike et al. [46] and Zelelew et al. [47] showed that bioethanol production was optimized both at temperature of $30^{\circ} \mathrm{C}$ and pH of 5.8 and 5.0, respectively. Similarly, in another study carried out by Rezania et al. [48] their report indicated that bioethanol production optimization was achieved at temperature of $32{ }^{\circ} \mathrm{C}$ and higher $\mathrm{pH}$ of 6.0 [48]. However, some authors reported optimized $\mathrm{pH}$ of 4.5 [49] and lower temperature of $25^{\circ} \mathrm{C}$ [50]. The differences observed in the optimized data could be attributed to different fermenting microorganisms used. Saccharomyces cerevisiae was used by Ike et al. [46] while Kluyveromyces sp. Y2 was used in this study. The highest ethanol yield of $0.424 \mathrm{mg} /$ $\mathrm{mL}$ reported in this study was low compared to what was reported by Belal [51] who reported 10,000-11,000 mg/ $\mathrm{mL}$ ethanol yield from rice chaff. The difference observed could be attributed to the additional treatment given to the chemical and enzyme treated substrate. Ultrasonic treatment of the hydrolyzed biomass has been mentioned to open up more sugars for fermentation [51]. The purity of the enzyme could considerably influence the amount of fermentable sugars available for yeast to ferment.

\section{Conclusion}

Three different lignocellulosic plant materials were studied for bioethanol production using locally isolated Aspergillus niger S48 and Kluyveromyces sp. Y2 for hydrolysis and fermentation, respectively. Rice chaff yielded more fermentable sugars $(1.07 \mathrm{mg} / \mathrm{mL})$ during hydrolysis with crude cellulase than mycelial inoculant than yam peel $0.87 \mathrm{mg} / \mathrm{mL}$ and ground nut shell $(0.75 \mathrm{mg} / \mathrm{mL})$. Bioethanol production was optimized at $12 \%$ rice chaff concentration, $\mathrm{pH}$ of 5.0 and temperature of $35^{\circ} \mathrm{C}$. Bioethanol yield of $424.2 \mathrm{mg} / \mathrm{mL}$ was obtained at the optimized conditions. Therefore, this study has revealed that locally isolated strains of Aspergillus niger S48 and Kluyveromyces sp. Y2 are suitable for the hydrolysis of pretreated plant biomass to generate fermentable sugars and fermentation of the sugars to bioethanol respectively from rice chaff which is produced as agricultural waste in Nigeria.

\section{Acknowledgements}

The authors acknowledge the use of laboratory facilities in the departments of Biotechnology and Microbiology, MAUTECH, Yola and grateful for the use of HPLC at American University of Nigeria, Yola.

Table 3 Optimization of bioethanol production at different fermentation parameters

\begin{tabular}{|c|c|c|c|c|c|}
\hline \multicolumn{2}{|c|}{ Substrate (Rice chaff) concentration (\%) } & \multirow{2}{*}{$\frac{\text { Temperature }{ }^{\circ} \mathrm{C}}{30}$} & \multirow{2}{*}{$\frac{\mathrm{pH}}{4.5}$} & \multirow{2}{*}{$\frac{\text { Retention time }(\mathrm{min})}{2.976}$} & \multirow{2}{*}{$\frac{\text { Ethanol yield }(\mathrm{mg} / \mathrm{mL})}{0.40}$} \\
\hline & 8 & & & & \\
\hline \multirow[t]{3}{*}{ First set } & 10 & 30 & 4.5 & 2.966 & 0.42 \\
\hline & 12 & 30 & 4.5 & 3.081 & 0.190 \\
\hline & 12 & 30 & 4.5 & 3.034 & 0.272 \\
\hline \multirow[t]{3}{*}{ Second set } & 12 & 35 & 4.5 & 3.0 .73 & 0.398 \\
\hline & 12 & 40 & 4.5 & 3.081 & 0.188 \\
\hline & 12 & 35 & 5.5 & 2.989 & 0.414 \\
\hline \multirow[t]{2}{*}{ Third set } & $* 12$ & 35 & 5.0 & 3.027 & 0.424 \\
\hline & 12 & 35 & 4.5 & 3.041 & 0.399 \\
\hline
\end{tabular}




\section{References}

[1] Bakare, V., Abdulsalami, M. S., Onusiriuka, B. C., Appah, J., Benjamin, B., Ndibe, T. O. "Ethanol production from lignocellulosic materials by fermentation process using yeast", Journal of Applied Sciences and Environmental Management, 23(5), pp. 875-882, 2019.

https://doi.org/10.4314/jasem.v23i5.17

[2] Jekayinfa, S. O., Orisaleye, J. I., Pecenka, R. "An Assessment of Potential Resources for Biomass Energy in Nigeria", Resources, 9(8), pp. 92-134, 2020.

https://doi.org/10.3390/resources9080092

[3] Galbe, M., Wallberg, O. "Pretreatment for biorefineries: a review of common methods for efficient utilization of lignocellulosic materials", Biotechnology for Biofuels, 12(1), pp. 294-320, 2019. https://doi.org/10.1186/s13068-019-1634-1

[4] Keles, S., Bilgen, S., Kaygusuz, K. "Biomass energy source in developing countries", Journal of Engineering Research and Applied Sciences, 6(1), pp. 566-576, 2017.

[5] Clauser, N. M., González, G., Mendieta, C. M., Kruyeniski,. J., Area, M. C., Valleyos, M. E. "Biomass Waste as Sustainable Raw Material for Energy and Fuels", Sustainability, 13(2), Article number: 794, 2021.

https://doi.org/10.3390/su13020794

[6] Pérez, J., Muñoz-Dorado, J., de la Rubia, T., Martínez, J. "Biodegradation and biological treatments of cellulose, hemicellulose and lignin: an overview", International Microbiology, 5(2), pp. 53-63, 2002.

https://doi.org/10.1007/s10123-002-0062-3

[7] Zhang, Y. H. P., Himmel, M. E., Mielenz, J. R. "Outlook for cellulase improvement: Screening and selection strategies", Biotechnology Advances, 24(5), pp. 452-481, 2006.

https://doi.org/10.1016/j.biotechadv.2006.03.003

[8] Maki, M., Leung, K. T., Qin, W. "The prospects of cellulase-producing bacteria for the bioconversion of lignocellulosic biomass", International Journal of Biological Sciences, 5(5), pp. 500-516, 2009.

https://doi.org/10.7150/ijbs.5.500

[9] Baig, K. S. "Interaction of enzymes with lignocellulosic materials: causes, mechanism and influencing factors", Bioresources and Bioprocessing, 7(1), Article number: 21, 2020.

https://doi.org/10.1186/s40643-020-00310-0

[10] Awoyale, A. A., Lokhat, D. "Experimental determination of the effects of pretreatment on selected Nigerian lignocellulosic biomass in bioethanol production", Scientific Reports, 11, Article number: 557, 2021.

[11] Vasić, K., Knez, Z., Leitgeb, M. "Bioethanol Production by Enzymatic Hydrolysis from Different Lignocellulosic Sources", Molecules, 26(3), Article number: 753, 2021. https://doi.org/10.3390/molecules26030753

[12] Brandt, M. E., Gade, L., McCloskey, C. B., Balajee, S. A. "Atypical Aspergillus flavus Isolates Associated with Chronic Azole Therapy", Journal of Clinical Microbiology, 47(10), pp. 3372-3375, 2009.

https://doi.org/10.1128/JCM.00671-09

[13] Harrigan, W. F., McCance, M. E. "Laboratory methods in Microbiology", Academic Press, London, UK, 1966.
[14] Hankin, L., Anagnostakis, S. L. "Solid media containing carboxymethylcellulose to detect CM cellulase activity of micro-organisms", Journal of General Microbiology, 98(1), pp. 109-115, 1977.

https://doi.org/10.1099/00221287-98-1-109

[15] Saliu, B. K. "Production of ethanol from some cellulosic waste biomass hydrolyzed using fungal cellulases", PhD Thesis, University of Ilorin, 2012.

[16] Owuama, C. I. "Microbiology Laboratory manual", Microtrend Digital Press, Yola, Nigeria, 2015.

[17] Navi, S. S, Bandyopadhyay, R., Hall, A. J., Bramel-Cox, P. J. "A pictorial guide for the identification of mold fungi on sorghum grain", International Crops Research, Institute for the Semi-Arid Tropics, Patancheru, Andhra Pradesh, India, 1999.

[18] Unachukwu, M. N., Nwakanma, C. "The fungi associated with the spoilage of bread in Enugu state", International Journal of Current Microbiology and Applied Sciences, 4(1), pp. 989-995, 2015.

[19] Ravimannan, N., Sevvel, P., Saarutharshan, S. "Study on fungi associated with spoilage of bread", International Journal of Advanced Research in Biological Sciences, 3(4), pp. 165-167, 2016.

[20] Ebabhi, A. M., Adekunle, A. A., Okunowo, W. O., Osuntoki, A. A. "Isolation and characterization of yeast strains from local food crops", Journal of Yeast and Fungal Research, 4(4), pp. 38-43, 2013. https://doi.org/10.5897/JYFR2013.0112

[21] Mandels, M., Weber, J. "The Production of Cellulases. Cellulases and their Applications", Advances in Chemistry, 95, pp. 391-414, 1969. https://doi.org/10.1021/ba-1969-0095.ch023

[22] Omojasola, P. F., Jilani, O. P. "Cellulase Production by Trichoderma longii, Aspergillus niger and Saccharomyces cerevisae Cultured on Waste Materials from Orange", Pakistan Journal of Biological Sciences, 11(20), pp. 2382-2388, 2008. https://doi.org/10.3923/pjbs.2008.2382.2388

[23] Mandels, M., Andreotti, R., Roche, C. "Measurement of saccharifying cellulase", In: 6th Biotechnology and Bioengineering symposium, Newton and Natick, MA, USA, 1976, pp. 21-33.

[24] Macris, B. J. "Production and Characterization of Cellulase and $\beta$-Glucosidase from a Mutant of Alternaria alternata", Applied Environmental Microbiology, 47(3), pp. 560-565, 1984.

[25] Ghose, T. K. "Measurement of cellulase activities", Pure and Applied Chemistry, 59(2), pp. 257-268, 1987. https://oi.org/10.1351/pac198759020257

[26] Fawole, M. O., Oso, B. A. "Characterization of Bacteria: Laboratory Manual of Microbiology", Spectrum Book Ltd, Ibadan, Nigeria, 2004.

[27] Vyas, A., Vyas, D., Vyas, K. M. "Production and optimization of cellulases on pretreated groundnut shell by Aspergillus terreus AV49", Journal of Scientific and Industrial Research, 64(4), pp. 281-286, 2005. [online] Available at: https://nopr.niscair.res.in/ handle/123456789/5139 [Accessed date: 20 January 2021]

[28] Mandels, M., Hontz, L., Nystrom, J. "Enzymatic hydrolysis of waste cellulose", Biotechnology and Bioengineering, 16(11), pp. 1471-1493, 1974. https://doi.org/10.1002/bit.260161105

[29] Caputi, A., Ueda, M., Brown, T. "Spectrophotometric Determination of Ethanol in Wine", American Journal of Enology Viticulture,19(3), pp. $160-165,1968$. 
[30] Abd Elrsoul, R. M. M., Bakhiet, S. E. A. "Optimization of Factors Influencing Cellulase Production by Some Indigenous Isolated Fungal Species", Jordan Journal of Biological Sciences, 11(1), pp. 31-36, 2018.

[31] Ordaz-Díaz, L. A., Rojas-Contreras, J. A., Flores-Vichi, F., Flores-Villegas, M. Y., Álvarez-Álvarez, C., Velasco-Vázquez, P., Bailón-Salas, A. M. "Quantification of Endoglucanase Activity based on Carboxymethyl Cellulose in Four Fungi Isolated from an Aerated Lagoon in a Pulp and Paper Mill", BioResources 11(3), pp. 7781-7789, 2016.

https://doi.org/10.15376/biores.11.3.7781-7789

[32] Vasco-Correa, J., Luo, X., Li, Y., Shah, A. "Comparative study of changes in composition and structure during sequential fungal pretreatment of non-sterile lignocellulosic feedstock", Industrial Crops and Products, 133, pp. 383-394, 2019.

https://doi.org/10.1016/j.indcrop.2019.03.043

[33] Saliu, B. K., Sani, A. "Bioethanol potentials of corn cob hydrolysed using cellulases of Aspergillus niger and Penicillium decumbens", EXCLI Journal, 11, pp. 468-479, 2012.

https://doi.org/10.17877/DE290R-14611

[34] Bakhiet, S. E. A., Al-Mokhtar, E. A. I. "Production of Citric Acid by Aspergillus niger Using Sugarcane Molasses as Substrate", Jordan Journal of Biological Sciences, 8(3), pp. 211-215, 2015.

[35] Alsohaili, S. A., Bani-Hasan, B. M. "Morphological and Molecular Identification of Fungi Isolated from Different Environmental Sources in the Northern Eastern Desert of Jordan", Jordan Journal of Biological Sciences, 11(3), pp. 329-337, 2018.

[36] Sohail, M., Siddiqi, R., Ahmad, A., Khan, S. A. "Cellulase production from Aspergillus niger MS82: effect of temperature and $\mathrm{pH}$ ", New Biotechnology, 25(6), pp. 437-441, 2009. https://doi.org/10.1016/j.nbt.2009.02.002

[37] Alawlaqi, M. M., Alharbi, A. A. "Exo- and endoglucanase production by Curvularia affinis using bean (Phaseolus vulgaris L.) waste biomass", Bioresources and Bioprocessing, 7(1), Article number: 6, 2020.

https://doi.org/10.1186/s40643-020-0296-y

[38] Rao, R. S., Bhadra, B., Shivaji, S. "Isolation and characterization of ethanol-producing yeasts from fruit and tree barks", Letters in Applied Microbiology, 47(1), pp. 19-24, 2016. https://doi.org/10.1111/j.1472-765X.2008.02380.x

[39] Tolulope Eunice, K. "Enzymatic and Dilute Acid Hydrolyses of Maize Stalk Substrate in Bio-ethanol Production", Journal of Energy, Environment and Chemical Engineering, 6(1), pp. 24-30, 2021.

https://doi.org/10.11648/j.jeece.20210601.14

[40] Manmai, N., Unpaprom, Y., Ramaraj, R. "Bioethanol production from sunflower stalk: application of chemical and biological pretreatments by response surface methodology (RSM)", Biomass Conversion and Biorefinery, 2020.

https://doi.org/10.1007/s13399-020-00602-7
[41] Ja'afaru, M. I., Fagade, O. E. "Cellulase Production and Enzymatic Hydrolysis of Some Selected Local Lignocellulosic Substrates by a Strain of Aspergillus niger", Research Journal of Biological Sciences, 2(1), pp. 13-16, 2007.

[42] Chand, P., Aruna, A., Maqsood, A. M., Rao, L. V. "Novel mutation method for increased cellulase production", Journal of Applied Microbiology. 98(2), pp. 318-323, 2005. http://doi.org/10.1111/j.1365-2672.2004.02453.x

[43] Narra, M., James, J. P., Balasubramanian, V. "Simultaneous saccharification and fermentation of delignified lignocellulosic biomass at high solid loadings by a newly isolated thermotolerant Kluyveromyces sp. for ethanol production", Bioresources Technology, 179, pp. 331-338, 2015. https://doi.org/10.1016/j.biortech.2014.11.116

[44] Mohamed, H., Abdel, N. A. Z., Maysa, M. A. A. "Optimization of the fermentation conditions for ethanol production by new thermotolerant strains of Kluyveromyces sp", African Journal of Microbiology Resources, 7(37), pp. 4550-4561, 2013. https://doi.org/10.5897/AJMR2013.5919

[45] Abada, E. A., Masrahi, Y. S., Al-Abboud, M. A., Alnashiri, H. M., El-Gayar, K. E. "Bioethanol Production with Cellulase Enzyme from Bacillus cereus Isolated from Sesame Seed Residue from the Jazan Region", BioResources, 13(2), pp. 3832-3845, 2018. https://doi.org/10.15376/biores.13.2.3832-3845

[46] Chukwuemeka, I. C., Ethel, O. C., Kalu, A. D., Odinakachi, O. H. "Bio-production of ethanol and biomass from wood particles and sawdust using conventional yeast", GSC Biological and Pharmaceutical Sciences, 11(1), pp. 069-077, 2020. https://doi.org/10.30574/gscbps.2020.11.1.0048

[47] Zelelew, D., Gebrehiwot, H., Fikre, W. "Feasibility of Bioethanol Production Potential and Optimization from Selected Lignocellulosic Waste Biomass", International Journal of Environmental Science and Natural Resources, 9(2), pp. 89-95, 2018. https://doi.org/10.19080/IJESNR.2018.09.555765

[48] Rezania, S., Mohamad, S. E., Yahya, A., Salleh, M. Md. "Bioethanol production from cocoa waste by locally isolated microorganism using response surface methodology", MOJ Biology and Medicine, 3(4), pp. 160-166, 2018.

https://doi.org/10.15406/mojbm.2018.03.00092

[49] Neelakandan, T., Usharani, G, Sekar, C. "Bioethanol production from cashew apple juice using Saccaharomyces cerevisiae", International Journal of Current Research, 11, pp. 151-153, 2010.

[50] Agrawal, T., Quraishi, A., Jadhav, S. K. "Bioethanol production from Madhuca latifolia $\mathrm{L}$. flowers by a newly isolated strain of Pichia kudriavzevii", Energy and Environment, 30(8), pp. 1477-1490, 2019. https://doi.org/10.1177/0958305x19852475

[51] Belal, E. B. "Bioethanol production from rice straw residues", Brazilian Journal of Microbiology, 44(1), pp. 225-234, 2013. https://doi.org/10.1590/S1517-83822013000100033 